\title{
The impact of type 2 diabetes mellitus on prognosis in patients with non-ST elevation myocardial infarction
}

\author{
Katarzyna Birkner, Bartosz Hudzik, Mariusz Gąsior \\ $3^{\text {rd }}$ Department of Cardiology, School of Medicine with the Division of Dentistry in Zabrze, \\ Medical University of Silesia in Katowice, Silesian Centre for Heart Disease in Zabrze, Poland \\ Kardiochirugia i Torakochirurgia Polska 2017; 14 (2): 127-132
}

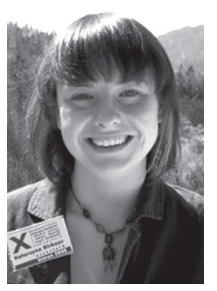

\begin{abstract}
Type 2 diabetes (T2D) is a recognized risk factor for acute coronary syndromes. There is currently no consensus concerning the intensification of antihyperglycemic treatment. According to the available guidelines, it seems that the goal is to achieve glycated hemoglobin $\left(\mathrm{HbA}_{1 \mathrm{c}}\right)$ levels below $7 \%$ and avoid hypoglycemia. The choice of a revascularization method is influenced by many factors, such as the anatomy of the coronary arteries, severity of atherosclerosis, anatomical location of lesions, and presence of comorbidities. However, in non-ST elevation myocardial infarction, determining the culprit lesion is often difficult based on ECG or angiography. Experts recommend coronary artery bypass grafting (CABG) in patients with type 2 diabetes and multivessel or complex (SYNTAX score exceeding 22 points) coronary artery disease in order to improve survival. Percutaneous coronary intervention should be considered as an alternative to CABG to control symptoms in patients with type 2 diabetes and less complex forms of the disease (i.e., SYNTAX score of 22 or lower).
\end{abstract}

Key words: type 2 diabetes mellitus, non-ST-elevation myocardial infarction, percutaneous coronary intervention, coronary artery bypass grafting.

\section{Streszczenie}

Cukrzyca typu 2 jest uznanym czynnikiem ryzyka wystąpienia ostrego zespołu wieńcowego. Wciąż nie ustalono konsensusu dotyczącego intensywności leczenia hipoglikemizującego. $\mathrm{Na}$ podstawie przytoczonych wytycznych wydaje się, że należy dążyć do stężenia hemoglobiny glikowanej $\left(\mathrm{HbA}_{1 c}\right)<7 \%$. Powinno się przy tym unikać epizodów hipoglikemii. Wybór optymalnej metody rewaskularyzacji wymaga dyskusji. Wpływa na niego wiele czynników, takich jak anatomia tętnic wieńcowych, stopień zaawansowania miażdżycy, lokalizacja zmian wymagających interwencji oraz choroby wspótistniejące (w tym występowanie cukrzycy). Jednak w przebiegu zawału serca bez przetrwałego uniesienia odcinka ST (NSTEMI) często trudno określić naczynie dozawałowe na podstawie badania elektrokardiograficznego bądź angiograficznego. W dostępnym piśmiennictwie pomostowanie aortalno-wieńcowe (CABG) zaleca się pacjentom z cukrzycą i wielonaczyniową lub złożoną (> 22 pkt wg skali SYNTAX) chorobą wieńcową w celu poprawy przeżycia wolnego od poważnych zdarzeń sercowo-naczyniowych. Możliwe jest również zastosowanie przezskórnej interwencji wieńcowej w celu kontroli objawów jako alternatywy CABG u pacjentów z cukrzycą i mniej złożoną postacią wielonaczyniowej choroby wieńcowej (tj. $\leq 22$ pkt wg skali SYNTAX) w przypadku konieczności rewaskularyzacji.

Słowa kluczowe: cukrzyca typu 2, zawat serca bez przetrwałego uniesienia odcinka ST, przezskórna interwencja wieńcowa, pomostowanie aortalno-wieńcowe.

without type 2 diabetes [2-4]. More and more studies show that type 2 diabetes also worsens the prognosis in this group [5]. Despite the increasingly more advanced methods of treating acute coronary syndrome, cardiovascular diseases are still the most common cause of death in highly developed countries. Because of the very high impact of environmental risk factors associated with unhealthy lifestyle leading to obesity, diabetes, hypertension, and atherosclerosis, prophylaxis is especially important in limiting the epidemic of diabetes and

Address for correspondence: Katarzyna Birkner MD, $3^{\text {rd }}$ Department of Cardiology, School of Medicine with the Division of Dentistry in Zabrze, Medical University of Silesia in Katowice, Silesian Centre for Heart Disease in Zabrze, 9 M. Curie-Skłodowskiej St, 41-800 Zabrze, Poland, phone: +48 604275 043, e-mail: kasiabirkner@wp.pl

Received: 25.03.2017, accepted: 18.04.2017. 
its complications. This is why successful management of patients with diabetes and cardiovascular diseases is highly dependent on interdisciplinary cooperation and informing the patients about the significance of their role in the process of treatment and prophylaxis.

\section{The effects of diabetes on the development of atherosclerosis}

Type 2 diabetes is characterized by the co-occurrence of insulin resistance and islet $\beta$-cell failure, usually accompanied by obesity and sedentary lifestyle [1].

The link between the pathogeneses of diabetes and atherosclerosis is hyperinsulinemia resulting from insulin resistance. Insulin resistance causes dyslipidemia and hyperglycemia, leading to reduced nitric oxide (NO) synthesis in blood vessel walls [6]. This makes diabetes a risk factor for atherosclerosis. Nitric oxide, originating from the amino acid L-arginine and oxygen, is responsible for the tension keeping blood vessels in a state of dilation, regulating the flow and pressure of blood. The regulation of vascular wall tension at the endothelial level mainly consists in the maintenance of equilibrium between the opposing effects of two mediators synthesized in the endothelium: nitric oxide, which dilates blood vessels, and endothelin 1, which constricts them. Other substances also participate in the maintenance of vascular homeostasis: prostacyclin, which synergizes with NO, as well as angiotensin II, thromboxane, and reactive oxygen species (ROS), which have an opposing effect. In cases of dyslipidemia and hyperglycemia, vascular homeostasis becomes disrupted.

At the same time, the changes in carbohydrate and lipid metabolism accompanying obesity and insulin resistance lead to the appearance of atherogenic lipoproteins, hyperglycemia, and increased concentration of free fatty acids. All of these factors disrupt the proper functioning of the epithelium, which increases its permeability and facilitates the activation of platelets and immune cells, especially macrophages, as well as their adhesion and migration within vascular walls. The ROS, cytokines, and growth factors created in this process inhibit the production of NO, while prostacyclins cause an increase in the level of platelet-activating factor, at the same time inhibiting the plasminogen activator. These processes lead to the formation of unstable atherosclerotic plaque and remodelling of the vascular wall, leading to the development of coronary heart disease [7].

Recent years have seen an increase in the number of publications concerning the influence of diabetes on blood platelet dysfunction [8]. Mean platelet volume is a parameter routinely measured in clinical practice, which makes it useful for the assessment of clinical characteristics. The measurement of mean platelet volume provides information on the activity of the platelets and their size, while their dysfunction is increasingly more often associated with a worse prognosis in patients with myocardial infarction [9]. The platelets of patients with diabetes exhibit dysregulation of several signaling pathways, which leads to an increase in their reactivity. They may then play a role not only in increasing the risk of myocardial infarction, but also in worsening the prognosis for patients with concurrent diabetes. This may also explain the more frequent occurrence of inadequate responses to antiplatelet treatment in patients with myocardial infarction and diabetes in comparison with patients without diabetes [10].

\section{Pharmacological treatment of patients with type $\mathbf{2}$ diabetes and myocardial infarction}

According to the most recent guidelines of the European Society of Cardiology, the following agents should be used in the pharmacological treatment of patients with non-ST elevation myocardial infarction (NSTEMI): acetylsalicylic acid, P2Y12 receptor inhibitors, $\beta$-adrenolytics, inhibitors of the renin-angiotensin-aldosterone system, and statins (recommendation class IA) [11]. There are no scientific reports indicating that patients with NSTEMI and concurrent type 2 diabetes should be treated differently. Large multicenter studies, such as TRITON-TIMI38 or PLATO, indicated that, in the group of patients with diabetes, the P2Y12 platelet receptor was more effectively blocked with the use of new generation drugs, such as ticagrelor or prasugrel, which was associated with an improved prognosis $[12,13]$. When choosing $\beta$-adrenolytics in the group of patients with type 2 diabetes, it seems to be more beneficial to use non-selective $\alpha$ and $\beta$-blockers (carvedilol) or nitric oxide synthesis modulators (nebivolol). These drugs improve prognosis in this group and have no unfavorable effect on glucose metabolism [14].

There is still no consensus with regard to the intensity of antihyperglycemic treatment. Does intensive pharmacotherapy, especially during the first days of acute coronary syndrome, offer more benefits in terms of prognosis? What are the target values of glycated hemoglobin concentration $\left(\mathrm{HbA}_{1 \mathrm{c}}\right)$ that should be achieved? Suleiman et al. examined 735 patients with previously undiagnosed type 2 diabetes admitted to the hospital with myocardial infarction [15]. Their research showed that hyperglycemia at the time of admission and persistent elevated blood glucose levels during further observation were correlated with significantly worse prognoses and higher mortality in this group of patients.

The ADVANCE study included 11140 patients with type 2 diabetes and a high risk of coronary heart disease [16]. The patients were divided into two groups - group 1 was treated intensively to reach $\mathrm{HbA}_{1 c}$ of $6.5 \%$, and group 2 was treated conventionally with the maintenance of $\mathrm{HbA}_{1 \mathrm{c}}$ at a level of $7.3 \%$; the follow-up period for both groups was 5 years. No differences in mortality from cardiovascular causes were found. The frequency of severe microvascular complications was lower among patients undergoing intensive treatment, but significant hypoglycemia was more common in this group. Similar results were obtained in the VADT study, in which 1791 intensively (target $\mathrm{HbA}_{1 \mathrm{c}}$ : 6.9\%) and conventionally (target $\mathrm{HbA}_{1 \mathrm{c}}: 8.4 \%$ ) treated patients with type 2 diabetes were followed up for 5.6 years [17]. Similarly to the ADVANCE study, no significant differences were found in the incidence of significant cardiovascular events, such as myocardial infarction or stroke. Microvascular complications did not occur more frequently in either of the studied groups. Similarly to 
the previous study, tendencies towards hypoglycemia were more frequent in the group undergoing intensive treatment.

The ORIGIN study included 12537 patients diagnosed with type 2 diagnosis or prediabetes, i.e. impaired fasting glucose (IFG) and impaired glucose tolerance (IGT) [18]. One patient group was treated intensively with insulin and glargin, aiming at a fasting glucose level of $<5.3 \mathrm{mmol} / \mathrm{l}$ ( $<95 \mathrm{mg} \%)$. The other group was treated conventionally, i.e., in line with the newest local guidelines. The group receiving conventional treatment also included patients in whom diabetes was diagnosed during the study. These patients received insulin at a maximum dose of up to $10 \mathrm{U} /$ day; metformin was discontinued. The follow-up period was 6.2 years. Similar incidence of cardiovascular complications was found in both groups, while severe hypoglycemia occurred significantly more frequently in the group receiving intensive treatment.

In 2008 the results of the ACCORD large clinical trial were published [19]. The study included 10251 patients assigned either to a group receiving intensive antihyperglycemic treatment (target $\mathrm{HbA}_{1 \mathrm{c}}:<6 \%$ ) or to a group treated conventionally (target $\mathrm{HbA}_{1 c}: 7.0-7.9 \%$ ). Cardiovascular incidents had been experienced in the past by $35 \%$ of the analyzed patients. The study was discontinued after 3.5 years due to the increased risk of death associated with intensive antihyperglycemic treatment $(\mathrm{HR}=1.22,95 \% \mathrm{Cl}: 1.01-1.46$, $p=0.04$ ). The rate of the primary endpoint (death from cardiovascular causes, non-fatal myocardial infarction, nonfatal stroke) was similar in both groups $(\mathrm{HR}=0.90,95 \% \mathrm{Cl}$ : $0.78-1.04, p=0.16)$. Hypoglycemia requiring treatment and body mass increased by more than $10 \mathrm{~kg}$ was observed more frequently among patients undergoing intensive treatment $(p<0.001)$. It was the first study to demonstrate the previously unknown risk associated with intensive treatment in high-risk patients with type 2 diabetes.

However, studies with follow-up periods longer than 10 years provided different conclusions. In the DCCT study [20] 1441 patients with type 1 diabetes were subjected to a follow-up of 17 years; they were also divided into two groups: one receiving intensive antihyperglycemic treatment and one treated conventionally. The study results showed that, in the group of patients undergoing intensive treatment, the incidence of adverse cardiovascular events was lower by $42 \%$. It was most likely associated with the fact that in patients with type 1 diabetes intensive antihyperglycemic therapy is always recommended.

In the UKPDS study [21], 5102 type 2 diabetes patients were followed up for 10 years; they were divided into two groups undergoing intensive and conventional treatment, respectively. In the conventional treatment group, only a restrictive diabetes diet was used. The patients treated intensively received sulfonylurea derivatives or insulin, while obese patients received metformin. At the end of the study, the patients treated intensively (i.e., with the use of insulin therapy or sulfonylurea derivatives) exhibited a significantly lower incidence of microvascular complications.

The studies listed above show that appropriate blood glucose control significantly reduces the incidence of car- diovascular events, but this effect becomes significant only after a very long follow-up period.

The most recent guidelines concerning the management of acute coronary syndromes without persistent ST elevation from 2015 suggest that in patients with acute coronary syndrome and glucose concentration $>10 \mathrm{mmol} / \mathrm{l}(>180 \mathrm{mg} / \mathrm{dl}$ ) a therapy reducing glucose concentration should be considered; target blood glucose should be adjusted to coexisting diseases and episodes of hypoglycemia should be avoided (recommendation class Ila, evidence level C) [11]. Moreover, both in the acute phase of the disease and during further follow-up, it is necessary to consider less restrictive blood glucose control in patients with more advanced cardiovascular diseases, elderly patients, as well as those with a longer duration of diabetes and more comorbidities (recommendation class Ila, evidence level C) [11].

On the other hand, the guidelines on the management of diabetes, prediabetes, and cardiovascular diseases published 2 years earlier in cooperation with the European Association for the Study of Diabetes, quite clearly specify the target blood glucose levels that should be achieved in order to reduce the risk of microvascular complications [22]. One recommendation (class IA) was to maintain strict blood glucose control with target $\mathrm{HbA}_{1 \mathrm{c}}$ values close to normal $(<7 \%$ or $<53 \mathrm{mmol} / \mathrm{mol}$ ) in patients with type 1 and 2 diabetes to reduce the risk of microvascular complications. But the evidence concerning the influence of target $\mathrm{HbA}_{1 c}$ values on the risk of microvascular complications is less convincing because of the complexity of the mechanisms associated with the chronic, progressive nature of diabetes and the influence of metabolic memory. In patients with type 1 and 2 diabetes, target $\mathrm{HbA}_{1 \mathrm{c}}$ values of $\leq 7.0 \%$ ( $\leq 53 \mathrm{mmol} /$ mol) should be considered to prevent cardiovascular diseases (recommendation class $\mathrm{IlaC}$ ). These guidelines also suggest that the fasting glucose concentration should be $<7.2 \mathrm{mmol} / \mathrm{l}(<120 \mathrm{mg} / \mathrm{dl})$ and $<9-10 \mathrm{mmol} / \mathrm{l}(<160-180$ $\mathrm{mg} / \mathrm{dl}$ ) after a meal, depending on the particular circumstances. Thus restrictive blood glucose control is possible in younger patients without comorbidities, who constitute only a small percentage of the population of patients with myocardial infarction and diabetes. There is, therefore, no consensus on the target blood glucose values in patients with cardiovascular diseases. Based on the mentioned guidelines, it may seem that we should strive for $\mathrm{HbA}_{1 \mathrm{c}}$ concentration of $<7 \%$, but in reality every decision about the intensification of antihyperglycemic treatment should be made individually for every patient, taking into consideration their age, duration of diabetes, and any potential complications of the disease. Moreover, episodes of hypoglycemia should be avoided.

\section{Invasive treatment of patients with non- ST-elevation myocardial infarction and type 2 diabetes - percutaneous or surgical revascularization?}

In recent years, the techniques used for percutaneous coronary interventions ( $\mathrm{PCl}$ ) have become much more advanced. The introduction of stents releasing antimitotic 
agents significantly reduced the occurrence of restenosis. As a result, $\mathrm{PCl}$ became the method of choice in the treatment of myocardial infarction [23]. In the case of NSTEMI, however, it is difficult to establish the culprit vessel based on electrocardiographic (no evident ischemic lesions or diffuse ischemia) or angiographic imaging (e.g., critical stenoses in more than one vessel). Such patients require special care during the selection of optimal treatment and potential qualification for coronary artery bypass grafting (CABG) or multi-stage $\mathrm{PCl}$. The choice of methods depends on numerous factors, such as the anatomy of coronary arteries, severity of atherosclerosis, location of the lesions requiring intervention, and coexisting diseases, including diabetes $[24,25]$. Because of the lack of large randomized controlled trials, it is difficult to establish the optimal method in the group of diabetes patients.

Hlatky et al. analyzed data from 10 randomized studies including 7812 patients in total [26]. These studies compared the effectiveness of $\mathrm{PCl}$ and $\mathrm{CABG}$ depending on the basic clinical characteristics. Analysis of the data demonstrated that long-term follow-up in the group of patients with type 2 diabetes and multivessel coronary disease, coronary artery bypass grafting seems to be the better strategy.

Sargin et al. compared the frequency of rehospitalization after myocardial revascularization [27]. Their study included 2664 patients with coronary heart disease, who were divided into two groups: group 1 included patients treated with CABG (1103 patients), and group 2 was constituted by patients undergoing PCI (1561 patients). The aim of the study was to compare the frequency of rehospitalization within 30 days and establish the risk factors for rehospitalization depending on the method of revascularization. No significant difference was found in the frequency of rehospitalization between the groups treated with percutaneous coronary interventions and coronary artery bypass grafting. Diabetes turned out to be a risk factor for rehospitalization within 30 days in both compared groups.

Bundhun et al. conducted a meta-analysis of 6 large randomized studies (SYNTAX, BARI, FREEDOM, CARDIa, MASS II, Kamlesh 2013), comparing the long-term treatment results of percutaneous coronary interventions and coronary artery bypass grafting in patients with type 2 diabetes treated with insulin [28]. In total 1297 patients with type 2 diabetes treated with insulin were analyzed: 639 patients underwent $C A B G$ and 658 were treated with $\mathrm{PCl}$. Lower mortality was found in the group treated with CABG. Moreover, this group had less cases of adverse cardiovascular and cerebrovascular events, and the patients were rehospitalized less frequently; however, a higher incidence of stroke was found in patients after CABG.

Naito et al. examined 483 patients aged $\geq 65$ with diabetes and multivessel coronary disease [29]; 256 patients were treated with $\mathrm{PCl}$ and 277 with CABG. The results of this study did not show any differences in mortality when comparing both methods of treating multivessel coronary disease.

Different results were achieved by Farkouh et al. in the large randomized FREEDOM study, which included 1900 patients with diabetes and multivessel coronary disease; the average follow-up was 3.8 years [30]. The endpoints of the study were: death from any cause, recurrent nonfatal infarction, or non-fatal stroke. In the group of patients treated with $\mathrm{PCl}$, death from any cause and recurrent nonfatal myocardial infarction occurred significantly more often. Only stroke was observed more frequently in the CABG group. Based on this study, it may seem that CABG is a better method of treatment in patients with diabetes and multivessel coronary disease.

Awad et al. analyzed a group of 3916 patients with diagnosed non-ST elevation myocardial infarction (NSTEMI), who were hospitalized in 11 medical centers [31]. Diabetes was diagnosed before hospital admission in 1457 patients (38\% of the entire analyzed group). The study compared, among others, treatment methods and intrahospital prognosis in patients with and without diabetes. It was demonstrated that patients with diabetes had a higher risk of severe complications, such as cardiogenic shock, heart failure, and death during hospitalization. The chosen method of revascularization was also analyzed; a tendency to conduct coronary artery bypass grafting was shown in the group of patients with coexisting diabetes.

In another multicenter randomized study, BARI 2D, Brooks et al. analyzed the data of 2368 patients with documented coronary heart disease and type 2 diabetes diagnosed at least 25 year earlier [23]. The aim of this study was not to compare CABG and $\mathrm{PCl}$ and the selection of treatment methods was associated with the anatomy of vessels and severity of atherosclerotic lesions, not with assignment to a given cohort. Still, the analysis of such a large number of patients revealed that individuals with diabetes and multivessel coronary disease undergo coronary artery bypass grafting more often.

Pandey et al. analyzed a subgroup of patients from the multicenter NCDR ACTION Registry-GWTG [32]. This subgroup included 74941 patients hospitalized due to non-ST elevation myocardial infarction with coexisting diabetes and multivessel coronary disease revealed in coronarography. The patients were divided into 3 groups based on the treatment method chosen: patients treated with CABG (36.4\%); patients treated with $\mathrm{PCl}$ using stents releasing an antimitotic agent (46.2\%), and patients treated conservatively $(17.3 \%)$. It was shown that only $1 / 3$ of patients with NSTEMI, diabetes, and multivessel coronary disease underwent CABG during hospitalization. This method of revascularization was used more frequently in patients with left main coronary artery disease, proximal left anterior descending (LAD) coronary artery stenosis, symptoms of heart failure and tachycardia, mild and moderate heart failure, and patients aged $<72$. At the same time, coronary artery bypass grafting was less frequently conducted in patients who received $\mathrm{P} 2 \mathrm{Y} 12$ receptor antagonists (clopidogrel, prasugrel) directly after admission, women, patients with previously diagnosed heart failure, dialysis patients, patients over 72 years of age, and patients who were overweight or obese. The previously mentioned guidelines from 
2015 concerning the management of acute coronary syndrome without persistent ST elevation included the following recommendations (Tab. I) [11].

Similar conclusions were drawn in the cardio-diabetological recommendations of 2013, stating that CABG is recommended (class $I A$ ) in patients with diabetes and multivessel or complex (SYNTAX score > 22) coronary disease in order to improve survival free of major cardiovascular events [22]. Another class IA recommendation stated that drug-eluting stent (DES) rather than bare-metal stents (BMS) should be used in $\mathrm{PCl}$ to reduce the risk of revascularization of the target vessel. It was also suggested that $\mathrm{PCl}$ should be considered as an alternative in order to control symptoms in patients with diabetes and less complex forms of multivessel coronary disease (i.e. SYNTAX score $\leq 22$ ) when revascularization is required, but this recommendation was included in class IlbB (not in IlaB, like in the guidelines for the management of NSTEMI from 2015).

\section{Conclusions}

It is undeniable that type 2 diabetes significantly accelerates the progress of atherosclerosis and thus increases the risk of acute coronary syndrome. At the same time, coexisting diabetes in patients with acute coronary syndrome significantly worsens the prognosis in this group of patients. Pharmacological treatment in patients with myocardial infarction is not significantly different in the populations with and without coexisting diabetes although there may be some preferences with regard to the choice of $\beta$-adrenolytics and treatment with $\mathrm{P} 2 \mathrm{Y} 12$ receptor inhibitors. It is, however, important to establish how to treat diabetes itself in the period of acute coronary syndrome. There still seems to be no consensus in this matter. The publications listed in this work explicitly show that in order to fully establish the influence of metabolic control on prognosis in patients with coronary heart disease, years or even decades of follow-up are required. There is still an insufficient number of studies with such a long follow-up period to unequivocally establish the intensity of antihyperglycemic treatment, target blood glucose values, or target concentration of glycated hemoglobin. Similar problems are associated with the selection of an appropriate invasive treatment method. In patients with type 2 diabetes and non-ST elevation myocardial infarction, coronary artery bypass grafting seems to be the better method of revascularization. However, the introduction of stents releasing antimitotic drugs significantly reduced the number of acute thromboses or restenoses in stents, improving the prognosis of patients with acute coronary syndrome. It is also undeniable that such patients require the so-called early invasive strategy, i.e., up to $72 \mathrm{~h}$ after hospitalization. It needs to be remembered, however, that the management of patients with type 2 diabetes and myocardial infarction is not limited to pharmacological and invasive treatment. Involving the patient in the treatment process is very important. Changes in lifestyle, increased physical activity, appropriate diabetes and antiatherosclerotic diet, chronic treatment,
Tab. I. Guidelines concerning the management of acute coronary syndrome without persistent ST elevation

\begin{tabular}{|c|c|c|}
\hline Recommendation & $\begin{array}{c}\text { Recommendation } \\
\text { class }\end{array}$ & $\begin{array}{c}\text { Evidence } \\
\text { level }\end{array}$ \\
\hline $\begin{array}{l}\text { In patients with diabetes and } \\
\text { NSTEMI, an invasive strategy } \\
\text { is recommended over } \\
\text { conservative management }\end{array}$ & I & A \\
\hline $\begin{array}{l}\text { In patients undergoing } \mathrm{PCl} \text {, it } \\
\text { is recommended to use new } \\
\text { generation DES stents instead } \\
\text { of BMS stents }\end{array}$ & I & $A$ \\
\hline $\begin{array}{l}\text { In patients with stabilized } \\
\text { multivessel CAD and acceptable } \\
\text { operative risk, CABG is } \\
\text { recommended over PCl }\end{array}$ & I & $A$ \\
\hline $\begin{array}{l}\text { In patients with stabilized } \\
\text { multivessel coronary disease and } \\
\text { SYNTAX score } \leq 22, \mathrm{PCl} \text { should be } \\
\text { considered as an alternative } \\
\text { to CABG }\end{array}$ & Ila & B \\
\hline
\end{tabular}

NSTEMI - non-ST-elevation myocardial infarction, $\mathrm{PCI}$ - percutaneous coronary intervention, DES - drug-eluting stent, BMS - bare metal stent, CAD - coronary artery disease, CABG - coronary artery bypass grafting.

and adequate rehabilitation, especially in the early period after acute coronary syndrome, are all indispensable.

\section{Disclosure}

Authors report no conflict of interest.

\section{References}

1. Grupa Robocza Europejskiego Towarzystwa Kardiologicznego (ESC) do spraw cukrzycy, stanu przedcukrzycowego i chorób układu sercowo-naczyniowego

1. we współpracy z Europejskim Towarzystwem Badań nad Cukrzycą (EASD). Wytyczne ESC dotyczące cukrzycy, stanu przedcukrzycowego i chorób układu sercowo-naczyniowego opracowane we współpracy z EASD. Kardiol Pol 2013; 71 (supl. XI): 319-394.

2. Glucose tolerance and mortality: comparison of WHO and American Diabetes Association diagnostic criteria. The DECODE study group. European Diabetes Epidemiology Group. Diabetes epidemiology: collaborative analysis of diagnostic criteria in Europe. Lancet 1999; 354: 617-621.

3. The DECODE Study Group. Is the current definition for diabetes relevant to mortality risk from all causes and cardiovascular and noncardiovascular diseases? Diabetes Care 2003; 26: 688-696.

4. Ning F, Tuomilehto J, Pyörälä K, Onat A, Söderberg S, Qiao Q. DECODE Study Group. Cardiovascular disease mortality in Europeans in relation to fasting and 2-h plasma glucose levels within a normoglycemic range. Diabetes Care 2010; 33: 2211-2216

5. Franklin K, Goldberg RJ, Spencer F, Klein W, Budaj A, Brieger D, Marre M, Steg PG, Gowda N, Gore JM. GRACE Investigators. Implications of diabetes in patients with acute coronary syndromes. The Global Registry of Acute Coronary Events. Arch Intern Med 2004; 164: 1457-1463.

6. Keymel S, Heinen Y, Balzer J, Rassaf T, Kelm M, Lauer T, Heiss C. Characterization of macro- and microvascular function and structure in patients with type 2 diabetes mellitus. Am J Cardiovasc Dis 2011; 1: 68-75.

7. Pansuria $\mathrm{M}, \mathrm{Xi} \mathrm{H}$, Li L, Yang XF, Wang $\mathrm{H}$. Insulin resistance, metabolic stress, and atherosclerosis. Front Biosci 2012; 4: 916-31.

8. Vinik Al, Erbas T, Park TS, Nolan R, Pittenger GL. Platelet dysfunction in type 2 diabetes. Diabetes Care 2001; 8: 288-294.

9. Huczek Z, Kochman J, Filipiak KJ, Horszczaruk GJ, Grabowski M, Piatkowski R, Wilczynska J, Zielinski A, Meier B, Opolski G. Mean platelet volume on admission predicts impaired reperfusion and long-term mortality in acute myocardial infarction treated with primary percutaneous coronary intervention. J Am Coll Cardiol 2005; 2: 284-290. 
10. Ferreiro JL, Angiolillo DJ. Diabetes and antiplatet therapy in acute coronary syndrome. Circulation 2011; 7: 798-813.

11. Grupa Robocza Europejskiego Towarzystwa Kardiologicznego (ESC) do spraw postępowania w ostrych zespołach wieńcowych bez przetrwałego uniesienia odcinka ST. Wytyczne ESC dotyczące postępowania w ostrych zespołach wieńcowych bez przetrwałego uniesienia odcinka ST w 2015 roku. Kardiol Pol 2015; 73: 1207-1294.

12. Filion KB, El Khoury F, Bielinski M, Schiller I, Dendukuri N, Brophy JM. Omega-3 fatty acids in high-risk cardiovascular patients: a meta-analysis of randomized controlled trials. BMC Cardiovasc Disord 2010; 10: 24.

13. Mozaffarian D, Wu JH. Omega-3 fatty acids and cardiovascular disease: effects on risk factors, molecular pathways, and clinical events. J Am Coll Cardiol 2011; 58: 2047-2067.

14. Fonseca VA. Effects of beta-blockers on glucose and lipid metabolism. Curr Med Res Opin 2010; 26: 615-629.

15. Suleiman M, Hammerman H, Boulos M, Kapeliovich MR, Suleiman A, Agmon Y, Markiewicz W, Aronson D. Fasting glucose is an important independent risk factor for 30-day mortality in patients with acute myocardial infarction. Am J Cardiol 2009; 111: 1013-1017.

16. ADVANCE Collaborative Group, Patel A, MacMahon S, Chalmers J, Neal B, Billot L, Woodward M, Marre M, Cooper M, Glasziou P, Grobbee D, Hamet P, Harrap S, Heller S, Liu L, Mancia G, Mogensen CE, Pan C, Poulter N, Rodgers A, Williams B, Bompoint S, de Galan BE, Joshi R, Travert F. Intensive blood glucose control and vascular outcomes in patients with type 2 diabe tes. N Engl J Med 2008; 358: 2560-2572.

17. Duckworth W, Abraira C, Moritz T, Reda D, Emanuele N, Reaven PD, Zieve FJ, Marks J, Davis SN, Hayward R, Warren SR, Goldman S, McCarren M, Vitek ME, Henderson WG, Huang GD; VADT Investigators. Glucose control and vascular complications in veterans with type 2 diabetes. N Engl J Med 2009; 360: 129-139.

18. ORIGIN Trial Investigators; Gerstein HC, Bosch J, Dagenais GR, Díaz R, Jung H, Maggioni AP, Pogue J, Probstfield J, Ramachandran A, Riddle MC, Rydén LE, Yusuf S. Basal insulin and cardiovascular and other outcomes in dysglycemia. N Eng J Med 2012; 367: 319-328.

19. Action to Control Cardiovascular Risk in Diabetes Study Group; Gerstein HC, Miller ME, Byington RP, Goff DC Jr, Bigger JT, Buse JB, Cushman WC, Genuth S, Ismail-Beigi F, Grimm RH Jr, Probstfield JL, Simons-Morton DG, Friedewald WT. Effects of intensive glucose lowering in type 2 diabetes. $N$ Engl J Med 2008; 358: 2545-2559.

20. Nathan DM, Cleary PA, Backlund JY, Genuth SM, Lachin JM, Orchard TJ, Raskin P, Zinman B; Diabetes Control and Complications Trial/Epidemiology of Diabetes Interventions and Complications (DCCT/EDIC) Study Research Group Intensive diabetes treatment and cardiovascular disease in patients with type 1 diabetes. N Engl J Med 2005; 353: 2643-2653.

21. Holman RR, Paul SK, Bethel MA, Matthews DR, Neil HA. 10-year follow-up of intensive glucose control in type 2 diabetes. N Engl J Med 2008; 359: 1577-1589.

22. Grupa Robocza Europejskiego Towarzystwa Kardiologicznego (ESC) do spraw cukrzycy, stanu przedcukrzycowego i chorób układu sercowo-naczyniowego we współpracy z Europejskim Towarzystwem Badań nad Cukrzycą (EASD). Wytyczne ESC dotyczące cukrzycy, stanu przedcukrzycowego i chorób układu sercowo-naczyniowego opracowane we współpracy z EASD. Kardiol Pol 2013; 71 (supl. XI): 319-394.
23. Puymirat E, Taldir G, Aissaoui N, Lemesle G, Lorgis L, Cuisset T, Bourlard P, Maillier B, Ducrocq G, Ferrieres J, Simon T, Danchin N. Use of invasive strategy in non-ST-segment elevation myocardial infarction is a major determinant of improved long-term survival: FAST-MI (French Registry of Acute Coronary Syndrome). JACC Cardiovasc Interv 2012; 5: 893-902.

24. Bypass Angioplasty Revascularization Investigation 2 Diabetes Study Group. Baseline characteristics of patients with diabetes and coronary artery disease enrolled in the Bypass Angioplasty Revascularization Investigation 2 Diabetes (BARI 2D) trial. Am Heart J 2008; 156: 528-536.

25. BARI 2D Study Group; Frye RL, August P, Brooks MM, Hardison RM, Kelsey SF, MacGregor JM, Orchard TJ, Chaitman BR, Genuth SM, Goldberg SH, Hlatky MA, Jones TL, Molitch ME, Nesto RW, Sako EY, Sobel BE. A randomized trial of therapies for type 2 diabetes and coronary artery disease. N Engl J Med 2009; 360: 2503-2515.

26. Hlatky MA, Boothroyd DB, Bravata DM, Boersma E, Booth J, Brooks MM, Carrié D, Clayton TC, Danchin N, Flather M, Hamm CW, Hueb WA, Kähler J, Kelsey SF, King SB, Kosinski AS, Lopes N, McDonald KM, Rodriguez A, Serruys $\mathrm{P}$, Sigwart $\mathrm{U}$, Stables RH, Owens DK, Pocock SJ. Coronary artery bypass surgery compared with percutaneous coronary interventions for multivessel disease: a collaborative analysis of individual patient data from ten randomised trials. Lancet 2009; 373: 1190-1197.

27. Sargin M, Tatlisu MA, Mete MT, Selcuk N, Bayer S, Akansel S, Aka SA, Eren M. Stent versus bypass: the reasons and risk factors for early readmission to hospital after myocardial revascularization. North Clin Istanb 2016; 3: 27-33.

28. Bundhun PK, Wu ZJ, Chen MH. Coronary artery bypass surgery compared with percutaneous coronary interventions in patients with insulin-treated type 2 diabetes mellitus: a systematic review and meta-analysis of 6 randomized controlled trials. Cardiovasc Diabetol 2016; 15: 2.

29. Naito R, Miyauchi K, Konishi H, Tsuboi S, Ogita M, Dohi T, Kajimoto K, Kasai T, Tamura H, Okazaki S, Isoda K, Yamamoto T, Amano A, Daida H. Comparing mortality between coronary artery bypass grafting and percutaneous coronary intervention with drug-eluting stents in elderly with diabetes and multivessel coronary disease. Heart Vessels 2016; 31: 1424-1429.

30. Farkouh ME, Domanski M, Sleeper LA, Siami FS, Dangas G, Mack M, Yang M, Cohen DJ, Rosenberg Y, Solomon SD, Desai AS, Gersh BJ, Magnuson EA, Lansky A, Boineau R, Weinberger J, Ramanathan K, Sousa JE, Rankin J, Bhargava B, Buse J, Hueb W, Smith CR, Muratov V, Bansilal S, King S $3^{\text {rd }}$, Bertrand M, Fuster V; FREEDOM Trial Investigators. Strategies for multivessel revascularization in patients with diabetes. N Engl J Med 2012; 367: 2375-2384.

31. Awad HH, Tisminetzky M, Metry D, McManus D, Yarzebski J, Gore JM, Goldberg RJ. Magnitude, treatment, and impact of diabetes mellitus in patients hospitalized with non-ST segment elevation myocardial infarction: a community-based study. Diab Vasc Dis Res 2016; 13: 13-20.

32. Pandey A, McGuire DK, de Lemos JA, Das SR, Berry JD, Brilakis ES, Banerjee S, Marso SP, Barsness GW, Simon DN, Roe M, Goyal A, Kosiborod M, Amsterdam EA, Kumbhani DJ. Revascularization trends in patients with diabetes mellitus and multivessel coronary artery disease presenting with non-ST elevation myocardial infarction: insights from the National Cardiovascular Data Registry Acute Coronary Treatment and Intervention Outcomes Network Registry-Get with the Guidelines (NCDR ACTION Registry-GWTG). Circ Cardiovasc Qual Outcomes 2016; 9: 197-205. 